each, entitled "L'influence séismogénique de certaines structures géologiques", by W. H. Wong, and "A graphic method to aid specific determination of Fusulinoids and some results of its application to the Fusulinae from N. China ", by J. S. Lee. There is also a note, with a plate of sections, on the first meteoric stone received by the Geological Survey of China, by C. Y. Hsieh. The seventh meeting was mainly occupied by reports of the results of the Third Asiatic Expedition, by H. F. Osborn, Roy C. Andrews, and W. Granger. A special meeting was also held to welcome Dr. Sven Hedin, who gave an address outlining his journeyings in Asia and their results.

\title{
OBITUARY.
}

\section{Robert Kidston, LL.D., D.Sc., F.R.S., F.R.S.E., F.G.S.}

BORN 28TH JUNE, 1852.

Died 13TH JULY, 1924.

The news of the death of Robert Kidston was received with a feeling almost of incredulity; though no longer young in years, he retained in a remarkable degree the enthusiasm and, apparently, the vigour of youth. He died at Gilfach Goch in South Wales, where he had gone to work with his friend Mr. Davies at a collection of Carboniferous plants. His end came with suddenness; such an end as he would have wished-in the midst of work. He leaves a widow and two daughters.

From the time when Kidston deliberately gave up the prospects of a business career to follow the compelling call of scientific research he devoted the greater part of his amazing energy to the study of Carboniferous floras. It was fortunate for science that he was able to take up the unremunerative occupation of original investigation. In early days he held for a time the post of Demonstrator in the botanical department of Edinburgh University, but most of his life was, one may almost say, consecrated to research. By extraordinary industry, by combining the enthusiasm of a collector with the scientific insight of a student, he acquired a systematic knowledge of Carboniferous plants which has never been surpassed. For many years Kidston has been recognized by his co-workers both at home and abroad as a master and authority to whom appeals were made with confidence, because he was not only exceptionally well informed on his own branch of Palaeobotany, but always direct and sincere in his criticisms, and ever ready to help others. Many younger men have special cause to remember with gratitude his kindness and his treatment of them as equals. It is often said that a man has limitations; who has not? The important point is that many men do not realize their limitations, and act accordingly. Kidston was transparently honest with himself as with his fellow workers; though on occasion dogmatic he was always open to conviction. It was a pleasure and an education to argue with him. His services to science, both pure and applied, though fully appreciated by his colleagues, have not been as fully recognized officially as they merited. He was 
elected a Fellow of the Royal Society in London in 1902; in 1916 the Geological Society awarded him the Murchison medal, and from the University of Glasgow he received the Honorary Degree of LL.D.

The earliest paper by him in my possession was published in 1882 ; the last, in collaboration with Professor Lang, of Manchester, in 1923. For more than forty years he consistently devoted himself to the intensive study of the later Palaeozoic floras; he demonstrated, as no other British Palaeobotanist has done, the value of fossil plants as guides to geological chronology; he acquired a wonderful knowledge of specific characters, and formed a collection of Carboniferous plants which is probably unsurpassed in quality.

After publishing a large number of papers on the macroscopic characters of Carboniferous species and on the vegetation of several coal-fields, he turned his attention to anatomical studies. In order thoroughly to qualify himself for this new line of research he attended laboratory courses at the University of Glasgow, under his friend Professor Bower. One result of this was a partnership with the late Professor Gwynne-Vaughan, which led to a valuable series of papers on fossil Osmundaceae and on many other types of extinct plants. After the premature death of the junior author, for whom Kidston felt a very warm affection, he was joined by Professor Lang, and to this very happy union we owe the most important contributions which have ever been made to our knowledge of the plants of the Devonian period.

Kidston was an expert photographer and draughtsman, and the value of his memoirs is enhanced by the excellence of the illustrations prepared by himself. With a retentive memory and a remarkable grasp of his subject, he combined a capacity for taking infinite pains and a passion for orderliness and method which excited the amusement and the envy of friends. From first to last he concentrated attention on Palaeozoic floras, and worked in close co-operation with the Geological Survey. To him more than to any other man the Survey is indebted. Since the days of Sir Joseph Hooker's short connexion with that Government Department, the official Staff has not included a Palaeobotanist ; but Kidston's knowledge was always at the disposal of the Director and was freely used. In his earliest papers he described specimens sent to him by the officers of the Geological Survey of Scotland, and at the time of his death he was engaged in the preparation of a Memoir on the Carboniferous floras which was to be completed in ten parts; four of these have been published. I have previously contributed to the Geological MAGAZINE a short account of this truly great work; it is with profound regret that one must now refer to it as a memorial left unfinished by him whose life-work it would have represented. I venture to express the hope that a way will be found of making an attempt to complete the great undertaking; there is no doubt much material prepared by the author, and there is certainly the stimulus of loyal devotion to his memory. 
The recollection of days spent with Kidston in his home at Stirling is a precious possession. He was a true friend, generous and unchanging, a student; and intensely human: unequalled in his knowledge of plants which grew in an era inconceivably remote, he cared equally for the plants which he cultivated with conspicuous success in his own garden. The loss of him is hard to bear because he was one who inspired affection as well as respect ; the memory of what he did for others and the sacrifices he made for the advancement of knowledge will long remain, but the written record of his work will endure still longer.

A. C. Seward.

\section{Charles William Andrews.}

BORN 1866.

DIED 25TH MAY, 1924.

Geologists and palaeontologists regret the premature death of Dr. C. W. Andrews, who has added so much to our knowledge of fossil vertebrates during the past thirty years. It was known to his friends that he had long been afflicted with a lingering illness, which he had borne with great fortitude; but he eagerly pursued his researches without intermission, and his end came peacefully in the midst of work.

Dr. Andrews was born at Hampstead in 1866 , and graduated in both science and arts in the University of London. He began his career as a schoolmaster, but in 1892 he competed for and obtained a vacant assistantship in the Department of Geology in the British Museum (Natural History). He now had ample opportunities for following his bent in natural science, and he achieved so much success in original research that he attained the London degree of D.Sc. in 1900.

When Dr. Andrews joined the staff of the British Museum, he was first entrusted with the curating of the fossil birds. Here he soon found new material, and like most British geologists of the last sixty years he began his career as a contributor to our science in the GEOLOGICAL Magazine. His first paper, published in 1894, described the remains of the largest known ratite bird from Madagascar, which he named Aepyornis titan. Although as an assistant curator he soon had to deal with all the higher vertebrates, he retained a special interest in birds to the end, and he wrote several valuable papers on the extinct birds of New Zealand, the Chatham Islands, and Patagonia, besides a notable account of a primitive tropic-bird (Prophaethon shrubsolei) from the London Clay of Sheppey.

Encouraged by the discoveries of Mr. Alfred N. Leeds in the Oxford Clay of Peterborough, Dr. Andrews also began early to take a special interest in the marine reptiles of the Jurassic period. In 1895 he described the growth-stages in the shoulder-girdle of a Plesiosaur, and in later years he made many contributions to our knowledge of the skull and other parts of the skeleton of the Sauropterygia, Ichthyopterygia, and Crocodilia. His results were summarized in the exhaustive Descriptive Catalogue of the Marine Reptiles of the Oxford Clay, 